\title{
The Michelle Markup: \\ The First Lady's impact on stock prices \\ of fashion companies
}

\author{
David Yermack \\ Professor of Finance \\ Stern School of Business, New York University \\ 44 West $4^{\text {th }}$ Street, Suite 9-160 \\ New York, NY 10012 \\ (212) 998-0357 \\ dyermack@stern.nyu.edu
}

April 25, 2010

\begin{abstract}
I analyze changes in apparel company stock prices when Michelle Obama wears designer outfits at major events. The First Lady's selections can create value exceeding \$100 million for companies that design and market her clothing. The effect is approximately $\$ 2.3$ billion during a 2009 European trip that the media labeled a "fashion faceoff" with her French counterpart Carla Bruni. However, firms whose clothing she chooses not to wear see their stock prices drop, and her net impact upon the industry amounts to a redistribution of value among firms. The First Lady's influence on fashion firms represents a private benefit of public office, similar to private benefits of control obtained by corporate managers.
\end{abstract}

I owe a large debt of gratitude to my wife, Rocio Aliaga Yermack, who proposed the topic for this paper and patiently shared with me her extensive knowledge of the fashion industry. My research assistant, NYU undergraduate student Andrew Wong, provided superb help in collecting data, identifying industry sources, and improving the exposition of the paper based upon his own deep knowledge of the fashion business. For helpful comments and discussions I thank my academic colleagues Ingolf Dittmann, Alex Edmans, Jonathan Karpoff, and Jeff Wurgler, and also seminar participants at the University of Washington. Part of this research was conducted while I was a visiting professor at Erasmus University Rotterdam. 


\section{The Michelle Markup: \\ The First Lady's impact on stock prices \\ of fashion companies}

\section{Introduction}

This paper analyzes how apparel company stock prices react when Michelle Obama makes public appearances wearing designer outfits. The First Lady's wardrobe seems wellsuited to a finance event study, because a cadre of followers anticipates, catalogues, and critiques her ensembles, providing publicity that could create substantial gains for firms in the clothing industry. The First Lady wears designs from a wide circle of suppliers, and considerable uncertainty about the identity of her outfitter precedes her appearances at important events.

I find that designer and retailer firms' stock prices rise significantly when Michelle Obama wears their clothing. In the 14-month period from November 2008 to December 2009, my estimates indicate that her public appearances led to gains exceeding $\$ 2.6$ billion in shareholder value for various clothiers, in a pattern that tracks her daily schedule. Her true impact is almost certainly greater, because many apparel companies are not publicly traded and we cannot study how their market value increases when the First Lady wears their clothing. However, I also find an opposite result for those fashion companies whose clothes are not worn by the First Lady on major public occasions: these firms experience losses in their stock values 
by about $0.4 \%$ just after events when the First Lady overlooks their designs. On balance,

Michelle Obama's impact upon the fashion industry appears to represent a pattern of value redistribution, rather than value creation.

The First Lady derives no direct financial benefit from the value she creates for apparel companies. However, she has the opportunity to influence trends in contemporary fashion and to promote the careers of designers whose creations she finds appealing. The prestige and visibility of her position enables the First Lady to confer these benefits upon clothiers, and her exercise of this influence is analogous to CEOs and large shareholders exercising the private benefits of control in the corporate world.

Private benefits of control have become a significant research issue in finance. As Dyck and Zingales (2004) discuss, the concept first appeared in a theory paper by Grossman and Hart (1980) and has become widely used to explain patterns of equity valuation, executive compensation, and related topics, in both inter-company and cross-country research. ${ }^{1}$ Private benefits of control include not only the cash flows from dividends and compensation, but also the intangible value of prestige, power, and public visibility enjoyed by CEOs and major shareholders. Extending the concept of private benefits of control to political figures seems straightforward, since they obtain intangible benefits of prestige, power and publicity similar to those enjoyed by corporate managers.

\footnotetext{
${ }^{1}$ Research on private benefits of control includes two seminal papers on the premiums paid by acquirers of large blocks of stock (Barclay and Holderness, 1989, and Dyck and Zingales, 2004), as well as approximately a dozen papers on the differential values of high-vote and low-vote stock issued by the same firm (see, e.g., Zingales, 1994). Related research has studied managers' media attention (Malmedier and Tate, 2009) and high-valued perquisites (Yermack, 2006). A series of papers beginning with LaPorta, Lopez-de-Silanes, Shleifer, and Vishny (1997) compares the approaches of different nations' legal systems to reducing private benefits of control, attempting to show connections between these regulations, the development of capital markets, and economic growth.
} 
I propose calling these rents the private benefits of public office. Research has begun to identify and value these benefits in various forms, such as the superior stock trading profits earned by U.S. Senators (Ziobrowski et. al, 2004) and election-related value increases for companies whose board members are ex-politicians (Goldman, Rocholl, and So, 2009). The private benefits of public office can explain why talented people sometimes set aside lucrative business careers to serve in government. Henry Paulson's 2006 decision to resign as CEO of Goldman, Sachs and become U.S. Secretary of the Treasury and Carlos Gutierrez's 2004 resignation as CEO of Kellogg in order to become U.S. Secretary of Commerce would be two of many such examples. While surely motivated by an altruistic desire to serve their country, these and other holders of public office are probably also drawn by the opportunity to influence civic affairs, accumulate social capital, and appear regularly in the international press.

My analysis finds that First Lady’s wardrobe choices can create value exceeding $\$ 100$ million for companies that design and market her outfits when she attends highly visible ceremonies such as state dinners or overseas summit meetings. The effect applies to stocks of both U.S. and foreign clothing companies and can be measured as large as $\$ 2.3$ billion for one observation, a week-long trip to Europe in April 2009 during which the First Lady appeared several times in public with Carla Bruni, an Italian fashion model married to the President of France. Even when she makes routine public visits to theaters, schools, and soup kitchens around Washington, Michelle Obama creates millions of dollars of shareholder value for certain fashion firms, whose stock rises about $0.5 \%$ when she wears an outfit in public, and about $2.3 \%$ when the occasion is a prominent political or diplomatic ceremony.

The First Lady's influence upon the apparel industry follows a longstanding pattern in 
which the tastes of major political figures have fueled demand for products among the public. Erdogan (1999) cites Queen Victoria's $19^{\text {th }}$ century association with Cadbury as one of the earliest known commercial endorsements. American examples include the iconic "teddy bear" stuffed toys, which were inspired by a cartoon about Theodore Roosevelt in 1902 and manufactured with the president's consent, and the James Bond spy thrillers, which took off in popularity after a spontaneous endorsement by John F. Kennedy in a magazine interview. Neither Roosevelt nor Kennedy (nor, I assume, Queen Victoria) received commissions for promoting these products, and I do not suggest that Michelle Obama obtains financial profits from her influence over contemporary fashion. Rather, her selections of designers and brands appear credible to the public precisely because of the absence of financial conflicts of interest, which typically cloud the value of paid celebrity endorsements.

While illustrating certain private benefits of public office, this paper also complements existing research in both finance and marketing. The close link between share prices and the First Lady's wardrobe provides insight into wealth creation in an industry in which the sources of economic value - public trends and attitudes about fashion - are intangible, fast-changing, and difficult to control or preserve. The large magnitudes of wealth redistribution tied to Michelle Obama's outfits suggest that credible celebrity endorsements can be much more valuable than estimated in studies such as Agrawal and Kamakura (1995), which found stock price increases in the neighborhood of $0.5 \%$ when endorsement contracts are announced. My results also provide validations of market efficiency. Stock prices react quickly to news of the First Lady's clothing selections, even though the source of much of the information (Internet blogs) is somewhat obscure. In addition, investors are savvy about attributing financial value not only to companies 
that own the designer labels worn by Michelle Obama, but also to the firms that retail the products. Moreover, investors quickly identify and punish those firms that the First Lady bypasses when choosing her wardrobe.

The remaining sections of this paper are organized as follows. Section II provides background on Michelle Obama and other First Ladies' impact upon the fashion world. Section III describes the dataset of apparel worn by the First Lady at public events. Section IV contains the main event study analysis and estimates of the value impact of Michelle Obama's wardrobe upon clothing company stock prices. Section V discusses potential private benefits obtained by the First Lady as a result of her choices of outfits, including an analysis of campaign contributions by fashion designers. Section VI examines anecdotal evidence about whether other major political figures influence upon fashion firms' values as profoundly as Michelle Obama does. Section VII concludes the paper.

\section{Michelle Obama and the fashion world}

Michelle Obama's impact upon contemporary fashion is unparalleled for any First Lady since Jacqueline Kennedy, though it has not been unusual for presidential wives' wardrobes to receive attention. In the 19th century Dolley Madison and Frances Folsom Cleveland were celebrated in the press for their senses of style; Frances Cleveland, who was just 21 when she married the President in an 1886 White House ceremony, popularized gowns with bare shoulders and caused American women to stop wearing bustles. ${ }^{2}$ In modern times, every First Lady since

\footnotetext{
${ }^{2}$ See the biography of Mrs. Cleveland posted at www.firstladies.org, the website of the National First Ladies' Library located in Canton, $\mathrm{OH}$.
} 
the Hoover administration (except for Bess Truman) has been photographed for Vogue magazine. Controversies have erupted over whether First Ladies should accept gifts of expensive designer clothing (Nancy Reagan) or wear mink coats financed by secret donors (Patricia Nixon, whose husband's "Checkers Speech" memorably asserted that she preferred "a respectable Republican cloth coat").

Michelle Obama favors outfits from avant-garde prestige designers who market their lines toward women with larger discretionary incomes. Her tastes appear to resonate with many women who aspire to join this market segment. However, the First Lady has also won a large following by wearing garments from mid-market chain stores such as Gap, Talbots, and Target, where millions of consumers shop each day in malls across the country. Her affinity for middle class retail chains was a theme of her October 27, 2008 television appearance on NBC's Tonight show, a broadcast that catalyzed public interest in her wardrobe. Her interview with Tonight host Jay Leno took place one week before Election Day, shortly after reports that the Republican National Committee had spent $\$ 150,000$ on clothing for vice presidential candidate Sarah Palin and her family. With Palin's attire having become an issue in the campaign, Leno queried Obama:

"I want to ask about your wardrobe. I'm guessing about 60 grand? Sixty, 70 thousand for that outfit?"

Obama responded that she had bought her clothes at a modest price from a mass-market retailer:

"Actually, this is a J. Crew ensemble. Ladies, we know J. Crew. You can get some good stuff online!"

The effect upon J. Crew Group Inc.'s stock price was electric, as it rose 8\% the next day 
and $25 \%$ by the end of the week. By December 31, 2009, about 14 months after the Tonight show interview, J. Crew's shares were $175 \%$ higher, a gain of about $\$ 1.8$ billion in market capitalization, after media reports had repeatedly linked the company with the First Lady.

As my database below indicates, the First Lady's wardrobe mixes outfits from exclusive designer shops with off-the-shelf items from mid-market stores, such as the J. Crew gloves with which she held the bible on January 20, 2009, as her husband took the presidential oath of office. Her patronage of national chain stores partly explains the sizeable value creation that can be attributed to her, since at least some of her outfits are marketed through high-volume retail outlets to very large numbers of consumers.

After reviewing many of Michelle Obama's comments to the press about her wardrobe, I find that she never acknowledges its business impact upon her vendors, instead making only vague statements such as,

"I wear what I love. That's what women have to focus on: what makes them happy and what makes them feel comfortable and beautiful. If I can have any impact, I want women to feel good about themselves and have fun with fashion" (Talley, 2009).

In interviews she rarely mentions individual designers. Instead, she seems more interested in publicizing her connections to mass-market retailers, having referred in different interviews to shopping trips at Target, Gap, and J. Crew. I contacted the White House press office to ask whether the First Lady considered the impact of her fashion selections upon the value of different companies, but in a reply E-mail I was told simply that "we do not comment on the First Lady's fashion selections." A 2009 appraisal by The New York Times fashion critic suggests that Michelle Obama's comments about mid-market retailers are a ruse to deflect scrutiny from the elite nature of her wardrobe: 
"Mrs. Obama's choices are all insider, apart from her shorts and those strategically worn plebe numbers from Target and Talbots. If she got any more insider, she'd be backing down a runway. She wears Rodarte, Jason Wu, Sophie Theallet, Narciso Rodriguez, Thakoon, Isabel Toledo and Rick Owens, labels that in terms of creativity and price are at the highest level of fashion. Go much higher and you hit couture" (Horyn, 2009).

However, the same critic also notes that the First Lady had earned a reputation for independence and judiciousness, ignoring trends to identify quality designers on her own:

"In Mrs. Obama, the fashion industry has found a woman it can admire but cannot completely possess. That's because she doesn't favor only one designer or a clique, as her predecessors did. Also, she avoids the appearance of being cozy with designers. That's why she's often described in terms reserved for a 1930s screen goddess: 'regal' and 'dazzling,' a woman not to be contended with so much as worshiped from afar"' (Horyn, 2009).

\section{Data description}

My analysis of fashion stocks' responses to Michelle Obama's wardrobe is derived from a database of apparel worn by her between November 1, 2008, and December 31, 2009. The database is compiled from postings on Internet blogs that track the First Lady's schedule of appearances and choices of outfits for each event. By far the most comprehensive of these blogs is "Mrs. O," www.mrs-o.org, which features a tagline of "Follow the Fashion of Mrs. O: What and Whom She's Wearing." This blog has a searchable, chronological record of the First Lady's significant public appearances, typically identifying the designer of her clothing and sometimes adding information about her footwear, jewelry, and accessories. I tabulate all this information and when necessary supplement it with postings from approximately ten similar Internet blogs, as well data from various news stories and fashion catalogues.

For each outfit, I identify the parent companies that have partial or complete equity 
interest in the firm that designs the garment and controls its intellectual property rights, if any. ${ }^{3}$ In addition to recording the designer for each outfit, I identify firms involved in its retailing. Sources of this information include company websites, business research tools such as Hoover's company profiles and The Wall Street Journal news archives, and www.style.com, an online repository of fashion industry news maintained by Vogue magazine.

As an example, on December 10, 2009, Michelle Obama wore a Calvin Klein gold jacket and dress to the ceremony in Oslo, Norway, at which President Obama received the Nobel Peace Prize. For this event, my database identifies Calvin Klein's corporate parent, Phillips-Van Heusen Corp., as the designer firm, and four additional publicly traded companies that carry the Calvin Klein line as retailer firms: Macy's Inc., Saks Inc., Nordstrom Inc., and Dillard's Inc. Often many more privately held firms, including numerous small fashion boutiques, may be involved as either designer or retailer companies, but I tabulate only those companies with publicly listed shares so that I can use their stocks prices to measure the real-time financial impact of the First Lady's apparel selections.

The database covers 189 separate public appearances by Michelle Obama on 139 dates between November 1, 2008, and December 31, 2009. Several dozen additional events covered by Internet blogs are dropped either because her outfits are not attributed to a specific designer or retailer, or because these roles are played only by private companies without listed stock prices. My sample for analysis includes 245 items classified variously as apparel, footwear, accessories, or jewelry, all of which are associated with at least one publicly traded designer or

\footnotetext{
${ }^{3}$ U.S. copyright law protects manufacturers' logos against copying but does not protect designs themselves, a position that is at odds with the more extensive copyright regimes of many other countries. The U.S. regulatory posture is the subject of an ongoing legislative debate which has divided the fashion industry itself. See Hemphill and Suk (2009).
} 
retailer. The sample start date of November 1, 2008, is chosen just after Michelle Obama's appearance with Jay Leno on the Tonight show, because inspection of earlier stock return data indicates little or no impact of her fashion choices upon share values prior to the Leno interview.

As shown in Table 1, I analyze 368 company-date observations in which a publicly listed firm is credited as either the designer, retailer or both (most event days involve multiple firms, sometimes one designer and as many as three or four retailers). These observations involve 29 companies, 23 of which are U.S.-based and six of which trade on overseas stock exchanges. The database would grow by many hundreds of additional observations if I tracked privately controlled firms in each of these categories, but because I am interested in stock price impacts I do not tabulate this data. Table 1 lists the sample companies, their home countries, and the total number appearances of each firm in the database overall and in each category. Figure 1 is a cross-tabulation of the relationships between the various designer and retailer firms. The figure shows several clear patterns. For example, most designer firms are closely held, and several large national retailers, including Macy’s, Saks, and Nordstrom, sell clothing created by numerous different designers who are favored by the First Lady. Most strikingly, the table shows that the First Lady wears outfits from dozens of different designers, some well-established and others up-and-coming.

I identify an additional 27 major apparel companies, 21 from the U.S. and 6 international, whose outfits are not worn by the First Lady during the sample period (some of them outfitted her earlier, on the presidential campaign trail). These firms are obtained the roster of the Council of Fashion Designers of America (CFDA) and lists of major public fashion companies. I include these firms in my analysis of stock prices as a control sample as I describe more fully below. 
Table 2 lists the 18 most significant public appearances by the First Lady during the sample period, which I choose based upon their visibility and political importance. These events generally involve major political meetings, ceremonies, or summit meetings with foreign leaders. The importance of most of these events, such as the Presidential inauguration, the G20 summit, and a White House state dinner, should be self-evident to the reader. All of these events received especially wide publicity, many of them on live national television, often with great attention by commentators to Michelle Obama's wardrobe selections. I will focus on these occasions especially for measuring the impact of the First Lady's outfits upon company stock prices. The right column of Table 2 lists the designer and main outfit worn on each occasion.

\section{Analysis}

I conduct event studies to determine whether fashion company stock prices react significantly when Michelle Obama wears their garments in public. For the 29 designer and retailer companies that have commercial associations with the First Lady's wardrobe, as well as the 27 additional apparel firms that do not, I pool the observations and estimate a one-factor market model regression of the following form, with standard errors clustered by company:

$$
R_{i t}=\alpha+\beta R m_{t} \gamma \delta_{i t}+\varepsilon_{i t}
$$

In the equation, $R_{i t}$ is the return on company $i$ 's stock on day $t, R m$ is the return on the relevant market index (which varies across firms depending upon the home country of each company), $\delta$ is an indicator variable that equals 1 for days in an event window around the time that the First Lady wears a particular company's clothing, and $\varepsilon$ is an error term. For most of the analysis below, I use a two-day event window including the day of the First Lady's public appearance 
and the subsequent day, since many blog postings do not initially identify the provenance of her outfits, adding the information later only after hours (or in some cases, days) of research reader postings. ${ }^{4}$ I estimate this regression using daily data for the entire calendar years 2008 and 2009. A significant estimate for the $\delta$ variable would be evidence of abnormal stock price movements during the event window.

I choose this estimation strategy for several reasons. Most companies have several event days in the database, and estimating the market model parameters and event study effects simultaneously in one equation avoids the overlap of estimation periods and event periods. In addition, fashion stocks performed well as a group in 2009 when most of my observations occur, and using older historical data to estimate market model parameters would lead to a spurious conclusion that most of these stocks had positive abnormal returns on most days of 2009 . A related problem is that during 2008, which would include the natural estimation period for a standard market model, the stock market suffered historically large losses, casting doubt upon the stability of market model parameters that one might estimate using data from that year. I cannot reasonably use an industry return as a benchmark in place of the market-wide return, because the set of publicly listed U.S. apparel companies includes virtually all the firms in my sample While a three-factor or four-factor model might seem more desirable than the one-factor model that I use, it is impossible for me to implement it because the companies I analyze trade

\footnotetext{
${ }^{4}$ For purposes of aligning events with stock returns, if an event concerning a U.S. company occurs in the morning or early afternoon of a weekday while the U.S. stock market is still open, I attribute it to that date. For events in the late afternoon, evening, weekends, or holidays, I use the next stock market trading day as the event day. For companies with U.S. stock listings, all timing classifications are made with respect to U.S. Eastern time, so that an evening event in Europe would be counted on the date that it occurred, since the U.S. stock markets would still be open. For companies whose stocks are listed in other countries, similar timing adjustments are used; for example, most European stock markets are closed by mid-morning in the U.S., so nearly all U.S. events are attributed to the subsequent trading day with respect to companies with European listings.
} 
on stock markets in seven different countries, including the U.S., France, Sweden, Germany, Switzerland, Italy, and Korea, and I do not have data for anything other than the overall market index for firms outside the U.S. As a robustness check, I reestimate the main models below in a four-factor specification using only observations for U.S.-listed stocks, and I obtain very similar results. Finally, there is strong reason to believe that the returns of the 56 stocks are correlated due to the commercial relationships that exist among them, so estimating abnormal returns in a single pooled regression permits clustering of standard errors to control for correlations of the error term among and within firms.

Table 3 presents two-day cumulative abnormal stock returns for various subsamples of companies. The top row of the table shows two-day CARs for the full sample, with results for the 18 major public appearances shown on the left and the entire sample shown on the right. The estimates indicate that share prices of either designer or retailer firms increase by an average of about $2.3 \%$ around dates of major public events, and by an average of about $0.5 \%$ on all days. Both mean returns are statistically significant at conventional levels. Further rows of the table show abnormal returns for various partitions of the full sample. The second and third rows show that designer and retailer firms experience almost identical stock gains around major public events at which their garments are worn. However, for the full sample which includes mainly routine Washington public appearances, only the retailer firms exhibit statistically significant returns. The gains illustrated in Table 3 appear to be permanent; if the event window is widened, abnormal returns remain positive and are even slightly higher if measured in a three-week period beginning on the event day and continuing for 14 additional trading days.

Across the entire sample, the abnormal stock returns translate into an aggregate gain of 
approximately $\$ 2.67$ billion in shareholder value for the sample companies. I calculate this statistic by multiplying each individual return by the market capitalization of the company involved one day prior to the event day. For the 189 separate events tracked in the database, this translates to an average increase of $\$ 14$ million in apparel company stock prices every time that the First Lady appears in public.

Some events have far larger estimates of value creation, and these gains closely track the amount of international press coverage. For example, on October 2, 2009 the First Lady traveled to Copenhagen to take part in Chicago's bid to host the 2016 Summer Olympic Games; the stocks of five fashion retailers linked to her outfit gained $\$ 643$ million over the next two days on a net-of-market, risk-adjusted basis. Similarly, Michelle Obama's appearances at a White House state dinner on November 24 and at the Nobel Peace Prize award ceremony in Oslo on December 10 led to abnormal value increases of $\$ 309$ million and $\$ 772$ million, respectively, for the fashion companies involved.

One event overshadows the rest of the sample in impact upon the value of apparel companies: the one-week European trip by President and Mrs. Obama between March 31 and April 6, 2009. The trip included stops in London, Strasbourg, Baden Baden, and Prague. The President attended G20 and NATO summit meetings, and many high profile public appearances took place including tea at Buckingham Palace with Queen Elizabeth II. Media attention was intense, especially when the First Lady appeared alongside her French counterpart, the former fashion model and songstress Carla Bruni. Their encouters, characterized as a "fashion faceoff" by much of the press, were televised worldwide and caused newspapers everywhere to publish evaluations of the two women's wardrobes. 
During the European trip, Michelle Obama wore outfits by several designers, and the stock prices of eight public companies, seven U.S. and one Swiss, stood to gain from their status as designers or retailers of the First Lady's ensembles. Figure 2 shows the results from a strategy of investing $\$ 1.00$ in each of these eight firms' stocks at closing prices on March 30, the day prior to the trip. Note that such a strategy would not have been possible to implement without advance inside knowledge of the First Lady's clothing selections. The figure shows that the eight stocks rose dramatically in sync with one another as worldwide interest in the trip increased. The eight firms' gains over the week ranged from 10\% (Talbots) to 35\% (Saks) and averaged $15.5 \%$. I searched news archives for confounding events at either the firm or industry level that might explain these rapid gains in share values but found none - in fact, one company (Macy's) saw its shares rise in spite of a debt downgrade. By comparison, the S\&P500 index, shown also in Figure 2, gained $6.1 \%$ in a market rally during the same period. The net creation of shareholder value for the eight firms was approximately $\$ 2.3$ billion when compared to increases in the S\&P500. More than half of the value gain went to Compagnie Financière Richemont SA, the Geneva-based owner of the Paris fashion house of designer Azzadine Alaia. Michelle Obama wore an Alaia dress to the dinner held April 3 for NATO leaders and their spouses and was praised for the diplomatic gesture of choosing a French design. She also wore an Alaia cardigan two days earlier to tea with the Queen at Buckingham Palace.

While some companies benefit dramatically from Michelle Obama's patronage, others are overlooked. Among the dozens of firms in the fashion industry, a large majority will be excluded from her wardrobe selections at any one event. For the 18 major events identified in Table 2, I identify the set of companies whose garments are not selected by the First Lady on 
each occasion and test whether her omissions lead to revaluation of these firms' share prices. Table 4 indicates that these companies lose value. Data on the left shows that for trading windows of length one through five days, company stock prices rise by approximately $2.0 \%$ if the First Lady wears their outfits, while data on the right shows a drop of about $0.4 \%$ in the shares of firms that she bypasses. These data indicate that transfers of value takes place, rather than organic creation of value, when the First Lady favors a particular designer or retailer.

Even though she captures none of it herself, the value projected onto fashion stocks by Michelle Obama dwarfs the earnings of any international celebrity or product endorser. According to Forbes magazine's most recent rankings, the highest-paid celebrity in the world is Oprah Winfrey at \$275 million annually, the highest-earning fashion model is Giselle Bundchen at $\$ 35$ million, and only a small group of models earn as much as $\$ 5$ million a year. ${ }^{5}$ The data would seem to support one of two interpretations: either that top celebrity endorsers are seriously underpaid, or alternatively, that Michelle Obama would rank at the top of such lists, very far ahead of anyone else, if she received fair market compensation for choosing and wearing her outfits.

Foreign trips provide an opportunity to test whether advance leakage of the First Lady's planned wardrobe occurs, potentially providing an opportunity for informed trading in apparel stocks in advance of her public appearances. Such speculation would seem more likely for foreign trips than domestic appearances, because her wardrobe needs to be packed at least several days in advance prior to traveling overseas, and a number of assistants and security

\footnotetext{
5 See "The World's Top Earning Models," April 30, 2008, and "The Celebrity 100," June 3, 2009, both posted at www.forbes.com. On the same website, Michelle Obama is no. 40 in Forbes' ranking of "The World's Most Powerful Women," August 19, 2009.
} 
personnel probably have advance knowledge of the outfits selected. The White House press office declined to respond to my question about whether any attempt is made to keep wardrobe selections confidential. I check for the possibility of a run-up in firms' stock prices prior to dates of Michelle Obama's major public appearances, both in the U.S. and abroad, and find no evidence that share prices advance before she wears companies' garments in public; returns for these firms are actually slightly negative in the two days prior to the event day.

\section{Discussion of Michelle Obama's private benefits of public office}

In measuring the value impact of Michelle Obama upon the fashion industry, I seek to identify an implicit personal benefit of her public service, the ability to send signals to the marketplace that channel billions of dollars of value toward those designers that she admires. I do not suggest that she obtains any of this value personally in any form other than the psychic rewards from seeing the careers of her favorite oufitters flourish.

Nevertheless, the value stream created by the First Lady's wardrobe is so large that one wonders if she might benefit from it at least indirectly. Such an attempt was made by one of Michelle Obama's predecessors, Nancy Reagan, who received gifts of expensive designer gowns, sometimes valued as high as $\$ 20,000$ each, and then wore the garments at public events during her husband's administration. Controversy arose when the Reagans did not disclose or pay taxes on the gifts. Mrs. Reagan responded to her critics by characterizing the transfers as "loans" and promising to donate some of the garments to museums. When criticism did not abate, she declared that she would end altogether her practice of borrowing gowns (Smith, 1982), but she nevertheless continued it quietly, without making required disclosures, throughout 
her eight years in the White House (Lamar, Peterzell and Traver, 1988). Designers who received publicity from Mrs. Reagan wearing their creations appear to have been pleased to cooperate in these arrangements; one told The New York Times in 1988 that 'It's wonderful. She's been a sensation for my business" (Roberts, 1988). However, Michelle Obama appears not to have followed any such practice involving gifts or loans of clothing, as she has categorically stated in many interviews that she purchases her entire wardrobe.

Campaign contributions represent another potential source of indirect benefits to the First Lady, since donations may assist in securing and prolonging her tenure. I search Federal Election Commission disclosures at www.opensecrets.org to obtain patterns of contributions by Michelle Obama's favorite designers or top executives of designer firms. Results appear in Table 5, which tabulates donations in three columns: which candidate a donor supported financially in the 2008 presidential primaries, which candidate he supported in the 2008 general election, and whether the donor contributed to party organizations such as Congressional or Senatorial campaign committees. Firms are ordered according to the number of times each designer appears in my database, and not all may legally contribute to any candidate because not all are U.S. citizens. In the first two columns, federal law limits gifts to individual candidates to $\$ 2,300$, and all donations recorded in the table were for that maximum amount. There is no limit on donations to party-wide campaign organizations.

Data in the first two columns of Table 5 indicate that Michelle Obama's favorite designers either supported Barack Obama in the general election or sat on the sidelines; none contributed to the campaign of his opponent John McCain. However, the group was not unanimous in its support of Obama in the hard-fought primary contest in the first half of 2008, as 
a number contributed to his opponent, Hilary Clinton, or to the Republican candidate Rudolph Giuliani. The most important data in the table appears in the right column, in which the largest donations are recorded. The table indicates that two major donors to party-wide campaign organizations exist among the top officers of Michelle Obama's favorite designer firms: the chief executive of J. Crew, Millard (Mickey) Drexler, who donated more than $\$ 96,000$ to various Democratic organizations in 2008, and the founder and chairman of Gap Stores, Donald Fisher, who gave more than $\$ 32,000$ to Republican organizations. Historical donation records indicate that both men have long track records of supporting these parties, as Drexler has donated more than $\$ 450,000$ since 1990 , nearly all of it to Democratic candidates or organizations, while Fisher has donated more than $\$ 1.2$ million in the same period, virtually all of it to Republican candidates or organizations.

Industry-wide data shows that clothing manufacturers as a group donated about $\$ 11.5$ million collectively to Democracts and $\$ 11.1$ million to Republicans in the 2007-08 election cycle, reversing a pattern in which the industry had supported Republicans by a margin of nearly 2-to-1 in the two most recent presidential campaign years. A large number of fashion designers also engaged in a fundraising project called "Runway for Change," which involved selling specially designed merchandise for the benefit of the Obama campaign. While the Democrats' success in attracting donations from the fashion industry may be partly attributable to Michelle Obama's appeal, it fits the overall patterns of donations in the 2007-08 campaign, during which the Democrats reversed a long-term trend by raising significantly more money than the Republicans. Despite their support of Obama and other Democratic candidates, clothing manufacturers are not a significant overall source of political contributions when compared to 
firms in other industries. No company in the apparel industry appears on the list of 98 companies, labor unions, or other organizations whose employees or political action committees donated \$1 million or more during the campaign; the largest donors tend to come from regulated industries such as finance, communications, or pharmaceuticals. I conclude that campaign donation data gives little indication of unusual contributions as a result of Michelle Obama's fashion selections.

While the First Lady does not appear to obtain any currently identifiable benefits related to her patronage of designers, her reputation as a fashion savant may prove marketable once she leaves the White House. She should almost certainly receive offers to serve as a corporate director, as an advisor or endorser for apparel companies, or as a contributor to fashion magazines or television shows such as Project Runway. Whether she capitalizes on such opportunities in the private sector remains to be seen; her intelligence, poise, and popularity would also seem to make her an ideal future candidate for public office, a path taken successfully by one of her predecessors as First Lady, Hilary Clinton.

\section{Other major political figures' impact upon fashion company values}

\section{A. Carla Bruni}

Carla Bruni became the First Lady of France in 2008 when she married President Nicolas Sarkozy at Elysée Palace. She was already well-known internationally as a fashion model and actress, having begun her career in 1986 in a campaign for Guess? jeans and subsequently working with many of the leading Parisian couturiers including Chanel, Dior, and Givenchy. As noted above, her joint appearances with Michelle Obama in 2009 created huge media interest 
and helped to create large gains in the shares of companies linked to her American counterpart.

The two first ladies take ironically different approaches to fashion. Michelle Obama, who grew up in a household of modest means, has an Ivy League and corporate background and a very traditional private life, with a stable marriage and family. Yet she wears avant-garde fashions from a range of designers that express a breadth of feelings and images. Carla Bruni, in contrast, grew up as an aristocratic heiress and has had an enormously complex private life including liaisons with rock stars and litigation over nude photography. Yet she dresses in a demure, elegant style, and since marrying Sarkozy she has favored the heavily traditional Dior label to the exclusion of nearly all others, a selection that likely enhances public perceptions of her patriotism and gravitas.

I attempt to replicate the event study analysis used for Michelle Obama's outfits by gathering the same type of information about Carla Bruni. Many Internet blogs and fashion sources also follow the French First Lady, and data from these sources indicates that she wears Dior outfits on nearly all public occasions. ${ }^{6}$ For instance, on her four-day U.S. trip in September 2009 she appeared publicly in five Dior outfits and departed from the brand only to go jogging in a Nike T-shirt. I find no statistically significant movements in the stock price of Dior surrounding high-profile events such as the joint appearances with Michelle Obama or a March 2008 visit to Buckingham Palace. This result is consistent with either of two interpretations, that Carla Bruni has no impact on the popularity of Dior, or, more likely, that her preference for the brand is so well-known that additional sightings of her wearing Dior are unsurprising to the

\footnotetext{
${ }^{6}$ I identified three exceptions, including a TV appearance to sing a duet with Harry Connick Jr. for which she wore Gap, and other public appearances at which she wore Gucci and Yves St. Laurent, both labels owned by the French fashion conglomerate PPR S.A. Neither the shares of Gap nor PPR moved significantly on these occasions.
} 
market. In fact, Dior shares have performed very well compared to the French market since the marriage of Bruni and Sarkozy on February 2, 2008, having dropped only 5\% by the end of 2009 compared to a $21 \%$ drop in the CAC40 index over the same interval.

\section{B. Sarah Palin}

During her whirlwind ten-week stint as the 2008 Republican Vice Presidential candidate, Sarah Palin attracted considerable scrutiny for her wardrobe. According to a story that broke late in the campaign, the Republican National Committee spent $\$ 150,000$ to outfit the Alaska Governor and her family in the days before the nominating convention. The centerpiece of their efforts - a Valentino designer jacket custom tailored for the candidate - was used by Democratic publicists to undermine Governor Palin's characterization of herself as a middle class "hockey mom."

The publicity surrounding her wardrobe probably did nothing to hurt the sales of the privately-held Valentino brand and other garments worn by Governor Palin on the campaign trail, but too few data points exist for statistical analysis of stock returns of retailer companies. The designer clothes were shelved after news of the spending spree became public, and the McCain campaign limited the governor's public appearances after a series of interview gaffes.

Some anecdotal evidence exists that Sarah Palin stimulated the sales of certain garments, footwear, and accessories. A September 2008 story in The Wall Street Journal (Byron, Saranow and Dodes, 2008) shortly after her nomination reported surging sales of the red Naughty Monkey high-heeled pumps that Governor Palin wore when introduced as Senator McCain's running mate. Purveyors of her designer eyeglasses, wig manufacturers who imitated her beehive 
hairstyle, and lipstick manufacturers all informally attributed sales increases to the Palin candidacy.

\section{Barack Obama}

President Obama has not achieved the iconic stature of his wife in the fashion world, and to date he has shown little personal interest in the affairs of the industry. ${ }^{7}$ Michelle Obama made the point in plain language in an interview reported by The New York Times:

"He doesn't understand fashion," she said. "He's always asking, 'Is that new? I haven't seen that before.' It's like: 'Why don't you mind your own business? Solve world hunger. Get out of my closet.' " Horyn (2009).

The President wears suits and trousers tailored by the 137-year-old Chicago manufacturer Hart Schaffner Marx, and the label received abundant publicity when Obama wore their suits to accept the Democratic nomination for president, to take the Presidential oath of office, and on other occasions. However, President Obama's adoption of the brand seems to have been of limited help, as its parent, Hartmarx Corp., filed for Chapter 11 bankruptcy protection on January 23, 2009, three days after his inauguration.

\section{Conclusions}

This paper studies how the wardrobe choices of First Lady Michelle Obama cause redistributions of value among firms in the apparel industry. I find that stock prices of designer and retailer companies rise significantly when the First Lady wears their outfits in public, and

${ }^{7}$ An exception occurred in January 2010, when The Weatherproof Garment Co. installed a giant billboard in Times Square showing the President wearing one of its coats while standing on the Great Wall of China. After the White House complained about unauthorized commercial use of the President's image, the billboard was taken down. 
that the increases are greatest for major public appearances such as summit meetings or addresses to Congress. These gains occur for both U.S. and foreign countries, and for both retailers and designers. However, fashion companies suffer losses in shareholder value when the First Lady bypasses them and does not wear their designs to a major public event.

The First Lady obtains no financial benefit from her influence upon the fashion industry, but she clearly has considerable power to promote certain companies or designers. This ability, which is partly due to her visibility in the role of First Lady, represents an economic rent that seems similar to the private benefits of control enjoyed by corporate managers. 


\section{References}

Agrawal, Jagdish, and Wagner A. Kamakura, 1995, The economic worth of celebrity endorsers: An event study analysis, Journal of Marketing 59, 56-62.

Barclay, Michael, and Clifford Holderness, 1989, Private benefits of control of public corporations, Journal of Financial Economics 25, 371-395.

Byron, Ellen, Jennifer Saranow, and Rachel Dodes, 2008, Palin's style sparks buying frenzy, and fashion firms rush to cash in, The Wall Street Journal, September 12, A1.

Dyck, Alexander, and Luigi Zingales, 2004, Private benefits of control: An international comparison, Journal of Finance 59, 537-600.

Erdogan, B. Zafer, 1995, Celebrity endorsement: A literature review, Journal of Marketing Management 15, 291-314.

Goldman, Eitan, Jörg Rocholl, and Jongil So, 2009, Do politically connected boards affect firm value? Review of Financial Studies 22, 2331-2360.

Grossman, Sanford, and Oliver Hart, 1980, Takeover bids, the free rider problem, and the theory of the corporation, Bell Journal of Economics 11, 42-69.

Hemphill, C. Scott, and Jeannie Suk, 2009, The law, culture, and economics of fashion, Stanford Law Review 61, 1147-1199.

Horyn, Cathy, 2009, The year in style: Wrapped in their identities, The New York Times, December 27, ST1.

Lamar, Jacob V., Jay Peterzell, and Nancy I. Traver, 1988, Nancy Reagan's little rule, Time, October 31 .

LaPorta, Rafael, Florencio Lopez-de-Silanes, Andrei Shleifer, and Robert Vishny, 1997, Legal determinants of external finance, Journal of Finance 52, 1131-1150.

Malmendier, Ulrike, and Geoffrey Tate, 2009, Superstar CEOs, Quarterly Journal of Economics 124, 1593-1638.

Roberts, Steven V., 1988, First Lady expresses "regrets" on wardrobe, The New York Times, October 18.

Smith, Hedrick, 1982, Nancy Reagan gives up dress designer loans, The New York Times, February 17. 
Talley, André Leon, 2009, Leading lady, Vogue, March.

Yermack, David, 2006, Flights of fancy: Corporate jets, CEO perquisites, and inferior shareholder returns, Journal of Financial Economics 80, 211-242.

Zingales, Luigi, 1994, The value of a voting right: A study of the Milan stock exchange experience, Review of Financial Studies 7, 125-148.

Ziobrowski, Alan J., Ping Cheng, James W. Boyd, and Brigitte J. Ziobrowski, 2004, Abnormal returns from the common stock investments of the U.S. Senate, Journal of Financial and Quantitative Analysis 39, 661-676. 


\section{Table 1}

\section{Composition of sample}

The table lists 29 publicly traded companies that either design or retail products worn in public appearances by Michelle Obama between November 1, 2008, and December 31, 2009. Data were compiled from Internet blogs, news articles, and fashion industry sources.

\begin{tabular}{|c|c|c|c|c|}
\hline Company & Home country & Total & Designer & Retailer \\
\hline Aeffe S.p.A & Italy & 17 & 17 & \\
\hline Cie. Financiere Richemont SA & Switzerland & 12 & 12 & \\
\hline Crocs Company, Inc. & United States & 1 & 1 & \\
\hline Dick's Sporting Goods, Inc. & United States & 4 & & 4 \\
\hline Dillard's Inc. & United States & 41 & & 41 \\
\hline DSW Inc. & United States & 25 & & 25 \\
\hline Finish Line Inc. & United States & 4 & & 4 \\
\hline Foot Locker Inc. & United States & 4 & & 4 \\
\hline Gap, Inc. & United States & 5 & 4 & 5 \\
\hline Hot Topic & United States & 1 & & 1 \\
\hline J. Crew Group, Inc. & United States & 18 & 18 & 18 \\
\hline JCPenny Co. Inc. & United States & 5 & & 5 \\
\hline Jones Apparel Group, Inc. & United States & 3 & 3 & \\
\hline Kohl's Corp. Inc. & United States & 1 & & 1 \\
\hline Limited Brands, Inc. & United States & 11 & & 11 \\
\hline Liz Claiborne Inc. & United States & 4 & 4 & \\
\hline LVMH SA & France & 2 & 2 & 2 \\
\hline Macy's Inc. & United States & 50 & & 50 \\
\hline Nike, Inc. & United States & 1 & 1 & \\
\hline Nordstrom Inc. & United States & 62 & & 62 \\
\hline Phillips-Van Heusen Corp. & United States & 1 & 1 & 1 \\
\hline PPR SA & France & 5 & 5 & \\
\hline Puma AG & Germany & 3 & 3 & \\
\hline Saks Inc. & United States & 75 & & 75 \\
\hline Sears Holdings Corp. Inc. & United States & 4 & & 4 \\
\hline SK Networks & Korea & 3 & 3 & 3 \\
\hline Target Inc. & United States & 2 & 1 & 2 \\
\hline The Talbots, Inc. & United States & 4 & & 4 \\
\hline Urban Outfitters, Inc. & United States & 4 & & 4 \\
\hline Totals & & 368 & 75 & 322 \\
\hline
\end{tabular}


Table 2

Major public appearances by Michelle Obama

The table lists the 18 most significant public appearances by the First Lady between November 1, 2008, and December $31,2009$.

These events include important U.S. political ceremonies, international summit meetings, and widely covered meetings with high government officials.

$\begin{array}{llll}\text { Date } & \text { Event } & \text { Location } & \text { Designer and outfit } \\ \text { November 4, 2008 } & \text { Election night victory celebration } & \text { Chicago } & \text { Narciso Rodriguez red and black dress } \\ \text { November 10, 2008 } & \text { Visit to George and Laura Bush at White House } & \text { Washington } & \text { Maria Pinto coral red dress } \\ \text { January 17, 2009 } & \text { Pre-inauguration visit to Lincoln Memorial } & \text { Washington } & \text { Narciso Rodriguez dress, coat and blouse } \\ \text { January 19, 2009 } & \text { Pre-inauguration concert } & \text { Washington } & \text { J. Crew sweater, blouse, skirt and belt } \\ \text { January 20, 2009 } & \text { Presidential inauguration } & \text { Washington } & \text { Isabel Toledo lemongrass coat and dress } \\ \text { February 24, 2009 } & \text { Joint session of Congress (State of the Union) } & \text { Washington } & \text { Narciso Rodriguez plum dress } \\ \text { April 1, 2009 } & \text { Visit to Queen Elizabeth at Buckingham Palace } & \text { London } & \text { Isabel Toledo ivory and black dress } \\ \text { April 2, 2009 } & \text { G20 meeting } & \text { London } & \text { Jason Wu blue dress } \\ \text { April 3, 2009 } & \text { NATO summit (with Carla Bruni) } & \text { Strasbourg, } & \text { Thakoon coat and dress (day); } \\ \text { June 6, 2009 } & \text { D-Day memorial ceremony (with Carla Bruni) } & \text { Paris and Caen } & \text { Narciso Rodriguez white dress } \\ \text { June 8, 2009 } & \text { Visit to 10 Downing Street } & \text { London } & \text { Jason Wu black and white dress } \\ \text { July 7, 2009 } & \text { Visit to President Medvedev's dacha } & \text { Moscow } & \text { VBH handbag } \\ \text { July 10, 2009 } & \text { Visit to Pope Benedict at St. Peter's Cathedral } & \text { Rome } & \text { Moschino black ensemble } \\ \text { September 9, 2009 } & \text { Joint session of Congress (healthcare address) } & \text { Washington } & \text { Moschino pink ensemble } \\ \text { September 24, 2009 } & \text { G20 summit meeting (with Carla Bruni) } & \text { Pittsburgh } & \text { Thakoon grey silk dress } \\ \text { October 2, 2009 } & \text { 2016 Olympics host city competition } & \text { Copenhagen } & \text { Michael Kors sunshine metallic dress } \\ \text { November 24, 2009 } & \text { State dinner for Prime Minister of India } & \text { Washington } & \text { Naeem Khan gown } \\ \text { December 10, 2009 } & \text { Nobel Peace Prize ceremony } & \text { Oslo } & \text { Calvin Klein gold dress and coat }\end{array}$




\section{Table 3}

Cumulative abnormal stock returns after public appearances by Michelle Obama

The table shows two-day cumulative abnormal stock returns for 29 apparel companies around the dates when First Lady Michelle Obama appears in public wearing the companies' garments. The event window includes the day of the appearance and the subsequent day, although it is shifted forward one day if the event occurs in the late afternoon or evening after the stock market is closed. Cumulative abnormal returns are calculated from a one-factor model using the market index from the home country of each fashion company. Events and garments are identified from Internet fashion blogs. Major events are those listed in Table 2.

\begin{tabular}{lrrrrrrrr} 
& \multicolumn{4}{c}{ Major events } & \multicolumn{5}{c}{ All events } \\
& Obs. & CAR & Z-stat & p-value & Obs. & CAR & Z-stat & p-value \\
Entire sample & 57 & $2.34 \%$ & 6.62 & $<0.001$ & 368 & $0.51 \%$ & 2.14 & 0.042 \\
& 13 & $2.37 \%$ & 3.36 & 0.002 & 75 & $0.07 \%$ & 0.06 & 0.950 \\
Designers & 49 & $2.44 \%$ & 7.60 & $<0.001$ & 322 & $0.68 \%$ & 3.61 & 0.001 \\
Retailers & 49 & $2.15 \%$ & 5.15 & $<0.001$ & 326 & $0.42 \%$ & 1.72 & 0.096 \\
U.S. stocks & 8 & $2.62 \%$ & 8.82 & $<0.001$ & 42 & $0.63 \%$ & 1.25 & 0.223 \\
Foreign stocks & & & & & & & &
\end{tabular}




\section{Table 4}

\section{Cumulative abnormal stock returns after major public appearances by Michelle Obama}

The table shows cumulative abnormal stock returns for 56 apparel companies around the dates of 18 major public events attended by First Lady Michelle Obama. The left half of the table shows data for 57 company-day observations for cases in which the First Lady wore an outfit or accessory for which the firm is either designer, retailer, or both. The right half of the table shows data for 912 company-day observations on days when a major event occurred but none of the company's garments were worn by the First Lady. Each event window begins on $t_{0}$, the day of the appearance, although it is shifted forward one day if the event occurs in the late afternoon or evening after the stock market is closed. Cumulative abnormal returns are calculated from a one-factor model using the market index from the home country of each fashion company. Events and garments are identified from Internet fashion blogs. Major events are those listed in Table 2.

\begin{tabular}{lrrrrrrrr} 
& \multicolumn{3}{c}{$\begin{array}{c}\text { Companies with garments } \\
\text { worn at event by the First Lady }\end{array}$} & \multicolumn{3}{c}{$\begin{array}{c}\text { Companies with garments } \\
\text { not worn at event }\end{array}$} \\
Interval & Obs. & CAR & Z-stat & p-value & Obs. & CAR & Z-stat & p-value \\
& & & & & & & & \\
$\mathrm{t}_{0}$ & 57 & $0.76 \%$ & 2.86 & 0.006 & 912 & $-0.16 \%$ & 1.30 & 0.198 \\
$\left(\mathrm{t}_{0}, \mathrm{t}_{+1}\right)$ & & $2.34 \%$ & 2.45 & 0.017 & & $-0.09 \%$ & 2.15 & 0.036 \\
$\left(\mathrm{t}_{0}, \mathrm{t}_{+2}\right)$ & & $2.02 \%$ & 1.88 & 0.065 & & $-0.40 \%$ & 4.90 & $<0.001$ \\
$\left(\mathrm{t}_{0}, \mathrm{t}_{+3}\right)$ & & $1.94 \%$ & 2.30 & 0.025 & $-0.48 \%$ & 3.76 & $<0.001$ \\
$\left(\mathrm{t}_{0}, \mathrm{t}_{+4}\right)$ & $2.17 \%$ & 1.90 & 0.063 & $-0.44 \%$ & 4.02 & $<0.001$
\end{tabular}




\section{Table 5}

\section{7-08 campaign contributions by Michelle Obama's favorite designers}

The table shows donations to political parties and candidates during the 2007-08 election cycle as reported to the Federal Election Commission. Designer firms are listed in the order in which they appear in the database of garments worn by Michelle Obama at public appearances between November 2008 and December 2009. Donation data is obtained from www.opensecrets.org. All contributions to primary and general election candidates are for the $\$ 2,300$ legal maximum.

\begin{tabular}{|c|c|c|c|c|c|}
\hline Designer Firm & $\begin{array}{l}\text { Times } \\
\text { Worn }\end{array}$ & Campaign Donor & $\begin{array}{l}\text { Primary } \\
\text { Election } \\
\text { Donee }\end{array}$ & $\begin{array}{l}\text { General } \\
\text { Election } \\
\text { Donee }\end{array}$ & $\begin{array}{l}\text { Indirect } \\
\text { Donations } \\
\text { (Party) }\end{array}$ \\
\hline Michael Kors & 27 & $\begin{array}{l}\text { Michael Kors, Designer } \\
\text { John D. Idol, CEO }\end{array}$ & $\begin{array}{l}\text { Clinton } \\
\text { Giuliani }\end{array}$ & $\begin{array}{l}\text { Obama } \\
\text { Obama }\end{array}$ & $\$ 10,000$ (Dem.) \\
\hline J. Crew & 24 & Millard S. Drexler, CEO & Obama & Obama & $\$ 96,900$ (Dem.) \\
\hline Jason $\mathrm{Wu}$ & 22 & None & & & \\
\hline Moschino & 22 & None & & & \\
\hline Narciso Rodriguez & 19 & Narciso Rodriguez, Designer & & Obama & $\$ 250$ (Dem.) \\
\hline Azzadine Alaia & 18 & None & & & \\
\hline Loree Rodkin & 12 & None & & & \\
\hline Thakoon & 11 & Thakoon Panichgul, Designer & Obama & Obama & \\
\hline Jimmy Choo & 9 & None & & & \\
\hline Maria Pinto & 8 & Maria Pinto, Designer & Obama & Obama & \\
\hline Peter Soronen & 6 & None & & & \\
\hline Erickson Beamon & 5 & None & & & \\
\hline Gap Stores & 5 & Donald G. Fisher, Chairman & Giuliani & & $\$ 32,900$ (Rep.) \\
\hline Lanvin & 5 & None & & & \\
\hline Hanii Y & 5 & None & & & \\
\hline Liz Claiborne & 5 & $\begin{array}{l}\text { Kay Koplovitz, Chairman } \\
\text { Paul R. Charron, Chairman }\end{array}$ & $\begin{array}{l}\text { Clinton } \\
\text { Clinton }\end{array}$ & & \\
\hline Isabel Toledo & 5 & Isabel Toledo, Designer & & Obama & \\
\hline Sonia Rykiel & 5 & None & & & \\
\hline Rick Owens & 5 & None & & & \\
\hline
\end{tabular}




\section{Figure 1}

\section{Links between designer and retail fashion companies}

The chart shows commercial relationships between designers and retailers in the fashion industry. Designers listed in the left column are included in a database of garments worn by First Lady Michelle Obama between November 2008 and December 2009. Relationships between designers and retailers are obtained from company websites and fashion publications.

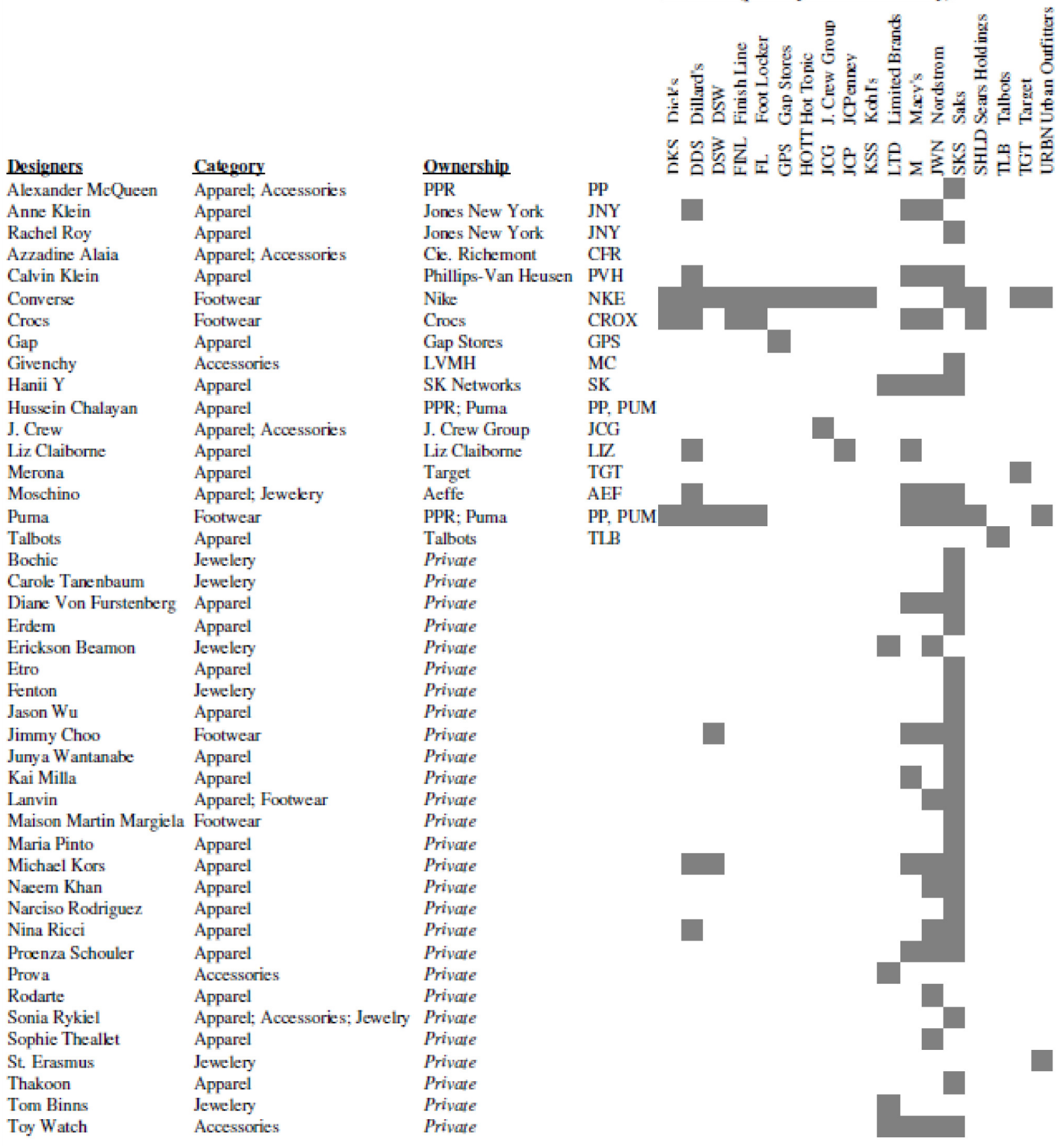




\section{Figure 2}

Performance of fashion company stocks during European trip by Michelle Obama

The chart shows the returns from investing in the stocks of eight fashion companies during the one-week trip of Barack and Michelle Obama to London, Strasbourg, and Prague between March 31 and April 6, 2009. The eight companies are either designers or retailers of outfits worn by the First Lady during the trip. The return on the S\&P500 index is shown for comparison purposes.

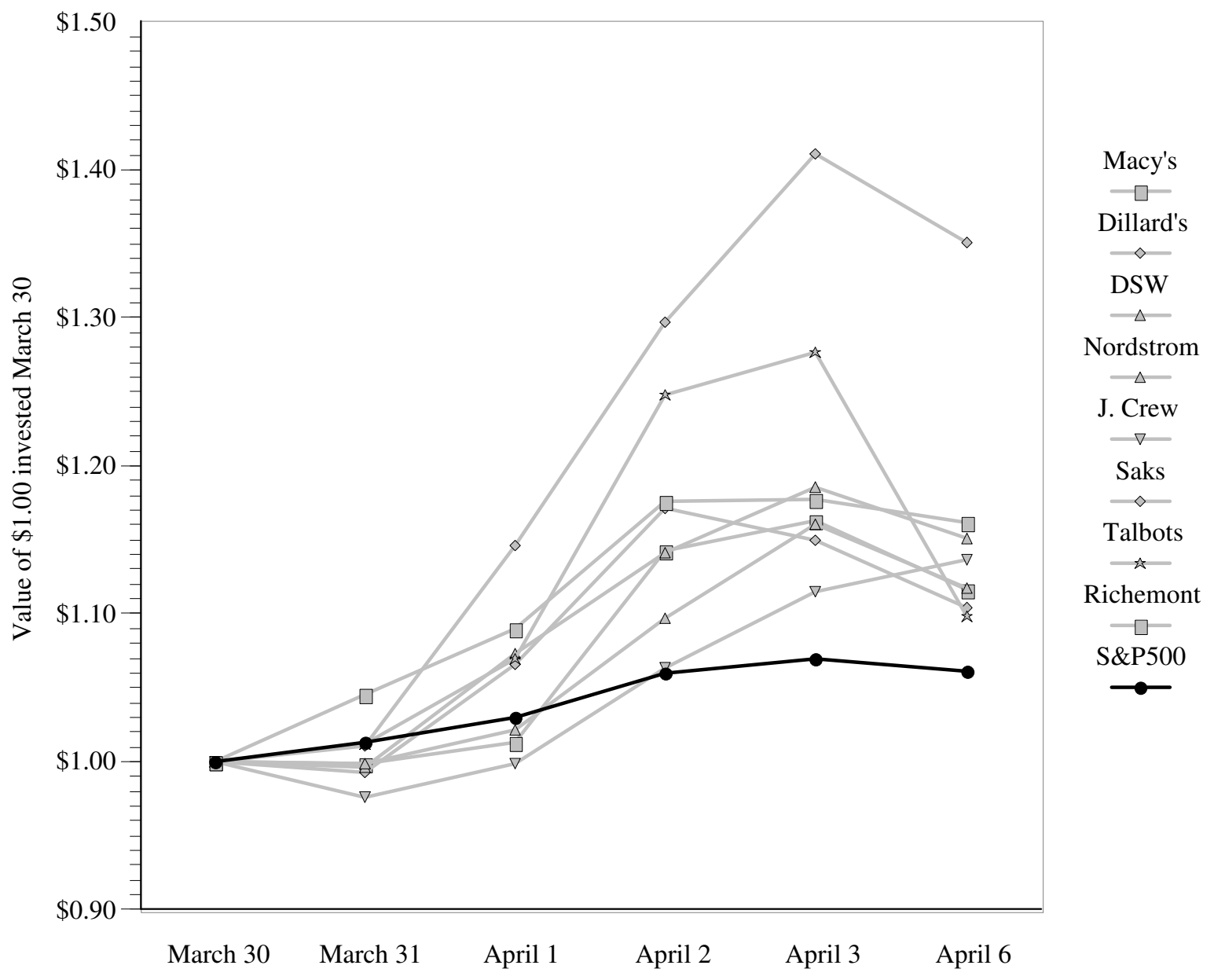

